\title{
PENGARUH KUALITAS PRODUK, HARGA DAN KUALITAS PELAYANAN TERHADAP KEPUASAN KONSUMEN KEDAI WARSU COFFE CAFE
}

\author{
Risatul Umami \\ Fakultas Bisnis Hukum dan Ilmu Sosial, Universitas Muhammadiyah Sidoarjo \\ As'at Rizal \\ Fakultas Bisnis Hukum dan Ilmu Sosial, Universitas Muhammadiyah Sidoarjo \\ email:asatrizal@gmail.com \\ Sumartik \\ Fakultas Bisnis Hukum dan Ilmu Sosial, Universitas Muhammadiyah Sidoarjo
}

\begin{abstract}
This research finds out the effect of product, price and service quality toward customer satisfaction both partially and simultaneously at Warsu Coffe Cafe. It is descriptive research with a quantitative method. The data were collected using questionnaires and documentation. The populations were the consumers who visited and bought a product in Warsu Coffe Cafe. The samples were 87 respondents that were chosen by using nonprobability sampling technique with incidental sampling type. The analysis technique used multiple linear regression. The result showed that both partially and simultaneously, the product, price, and service quality affect customer satisfaction. The most dominant influence is product quality on customer satisfaction, it shows that the Warsu Coffee Cafe has good product quality.
\end{abstract}

Keywords: product quality, price, and service quality, customer satisfaction

\section{PENDAHULUAN}

Di era globalisasi saat ini dunia bisnis semakin hari semakin berkembang. Hal ini membuat perusahaan tidak akan terlepas dari persaingan yang ada sehingga perusahaan dituntut untuk memberikan sistem pemasaran yang baik pada perusahaan yang bergerak dalam bidang industri ataupun jasa.

Di Indonesia salah satu bisnis yang mengalami perkembangan pesat dan merasakan ketatnya persaingan saat ini adalah bisnis dalam bidang kuliner. Persaingan yang sengit dapat dibuktikan dengan semakin banyaknya penyedia bisnis kuliner yang menyediakan dan menawarkan produk yang sama akan tetapi ada perbedaan dari segi pelayanan maupun harga dari masing-masing bisnis kuliner.

Sebuah penyedia layanan dituntut untuk memberikan suatu produk atau jasa dengan kualitas yang baik, baik dalam segi kualitas produk, kualitas pelayanan ataupun dapat memberikan harga produk atau jasa yang lebih terjangkau, sehingga konsumen akan merasa kebutuhannya terpenuhi serta akan menciptakan sebuah kepuasan dari dalam diri konsumen.
Kota Sidoarjo menduduki kategori sebagai kota terbesar di Jawa Timur. Kota ini terus mengalami perkembangan seperti bertambahnya lembaga pendidikan, pusat perdagangan, industri dan perkantoran. Perkembangan pusat pendidikan yang ada di kota Sidoarjo membuat pertumbuhan penduduk remaja yang semakin padat di kota tersebut. Situasi seperti ini dimanfaatkan oleh para pembisnis untuk menciptakan maupun pengembangan sebuah bisnis guna untuk mendapatkan keuntungan yang lebih.

Fenomena menjamurnya bisnis yang ada di kota Sidoarjo, yang di mulai dari skala kecil seperti warung-warung dan angkringan, bisnis kuliner yang berskala menengah seperti depot, rumah makan dan cafe. Sampai bisnis yang skalanya besar seperti restoran. Hal ini menjadikan daya tarik penulis untuk meneliti bisnis kuliner yang berfokus pada salah satu kuliner yaitu Kedai Warsu Coffe. Salah satu bisnis kuliner yang ada di kabupaten Sidoarjo.

Kedai Warsu Coffe ini menyediakan berbagai menu makanan serta minuman. Tetapi, Kedai ini terkenal dengan minuman favorit para konsumen yaitu susu murni dan minuman herbal seperti 
wedang jahe STMJ dan sebagainya. Minuman itulah yang membuat pada konsumen terus mendatangi Kedai Warsu Coffe untuk membeli produk favorit yang tersedia. Kedai Warsu Coffe selalu memberikan kualitas produk yang menyehatkan serta selalu menjaga nilai herbal yang terkandung dari bahan peracik makanan serta minuman. Untuk makanan yang di tawarkan di Kedai ini juga tersaji rapi dengan tambahan hiasan yang dapat mempercantik sajian produk makanan atau minumannya. Karena bahan yang di gunakan dalam meracik makanan ataupun minuman di Kedai ini sangat berkualitas, maka tingkat kualitas produk dalam segi rasa dan khasiat sangat baik untuk kesehatan. Semua strategi yang dilakukan oleh Kedai Warsu Coffe dalam memberikan kualitas produk, penetapan harga serta kualitas pelayanan, semata-mata untuk membuat konsumen merasa puas dengan sajian yang di berikan oleh Kedai Warsu Coffe, sehingga jika konsumen merasa puas maka konsumen akan melakukan pembelian ulang dan akan menjadi pelanggan yang loyal.

\section{KAJIAN TEORI}

Memperkuat analisis di bawah ini dikemukakan beberapa teori yang berkaitan dengan variabel yang diteliti.

\section{Pemasaran}

Menurut Swastha dan Irawan (2003) pemasaran adalah suatu kegiatan pokok yang dilakukan oleh seorang pengusaha didalam usahanya dengan tujuan untuk mempertahankan kelangsungan hidupnya untuk dapat berkembang dan mendapatkan sebuah laba. Menurut [10] menyatakan bahwa pemasaran adalah suatu proses sosial manajerial dimana dapat membuat individu dan keolmpok akan mendapatkan apa yang mereka butuhkan serta inginkan lewat penciptaan serta pertukaran timbal balik produk dan nilai dengan orang lain.

\section{Produk}

Menurut Alma (2000) menyatakan bahwa produk adalah seperangkat atribut yang berwujud ataupun tidak berwujud, yang termasuk didalamnya adalah warna, harga, Brand toko yang menjual, dan pelayanan pabrik serta pengecer yang diterima oleh pembeli dalam rangka untuk memuaskan keinginannya. Menurut Lupiyoadi (2011) menyatakan bahwa produk merupakan keseluruan dari konsep objek atau suatu proses yang memberikan sejumlah nilai kepada konsumen.

\section{Kualitas Produk}

Menurut Runtunuwu dan Oroh (2014), kualitas produk adalah sebuah kemampuan dari suatu produk dalam rangka melaksanakan sebuah fungsi yang meliputi kehandalan, daya tahan, kemudahan operasi, ketepatan, kebaikan dari produk, ataupun sebuah atribut bernilai lainnya.

\section{Harga}

Menurut Kotler dan Keller (2001), harga adalah satu-satunya elemen bauran pemasaran yang menghasilkan pendapatan. Harga adalah juga merupakan salah satu elemen yang paling dapat dikatakan fleksible dari bauran pemasaran.

\section{Kualitas Pelayanan}

Menurut Yuniar dan Setyorini (2015), kualitas pelayanan adalah kualitas (quality) totalitas fitur dan karakteristik produk atau jasa dimana bergantung pada kemampuannya dalam memuaskan kebutuhan yang di nyatakan atau tersirat.

\section{Hipotesis}

\section{Hubungan Kualitas Produk Dengan Kepuasan Konsumen}

Menurut Solihin (2014) memaparkan bahwa sebuah produk disebut memiliki kualitas yang lebih baik dibandingkan produk lainnya apabila produk tersebut memiliki kinerja lebih baik dalam memuaskan kebutuhan konsumen.

H1. Kualitas Produk berpengaruh signifikan terhadap kepuasan konsumen

\section{Hubungan Harga Dengan Kepuasan Konsumen}

Menurut Handoko (2016) harga seringkali digunakan sebagai indikator nilai bilamana harga tersebut dihubungkan dengan manfaat yang dirasakan atas suatu barang atau jasa. Dengan demikian dapat disimpulkan bahwa pada tingkat harga tertentu, bila manfaat yang dirasakan konsumen meningkat, maka nilainya akan meningkat pula, sehingga akan muncul kepuasan pada diri konsumen. Dengan kata lain, pada tingkat harga tertentu yang telah dikeluarkan, konsumen dapat merasakan manfaat dari produk yang telah dibelinya dan konsumen akan merasa puas apabila manfaat yang mereka dapatkan sebanding atau bahkan lebih tinggi dari nominal uang yang mereka keluarkan. 
H2. Harga Berpengaruh signifikan terhadap Kepuasan Konsumen

\section{Hubungan Kualitas Pelayanan Terhadap Kepuasan Konsumen}

Menurut Amrullah, Siburian, dan Zainurosalamia (2016) pelayanan terbaik pada pelanggan (excelent) dan tingkat kualitas pelayanan merupakan cara terbaik yang konsisten untuk dapat mempertemukan harapan konsumen (standar pelayanan eksternal dan biaya) dan sistem kinerja cara pelayanan (standar pelayanan internal, biaya dan keuntungan). Teori lain dipaparkan oleh [3] kualitas layanan merupakan sebuh komponen penting yang merupakan penentu yang penting dalam pencapaian kepuasan.

H3. Kulaitas layanan berpengaruh signifikan terhadap kepuasan konsumen

\section{METODE PENELITIAN}

\section{Pendekatan Penelitian}

Pendekatan yang digunakan dalam penelitian ini adalah pendekatan kuantitatif yaitu pendekatan yang menitik beratkan pada pengujian hipotesis yang disertai dengan studi empiris jurnal sebelumnya sebagai pelengkap untuk mendukung kesimpulan secara matematis atau statistik. Pendekatan kuantitatif diambil karena melalui pendekatan ini proses penelitian dapat dilakukan secara terstruktur dan menggunakan sampel penelitian dalam jumlah besar yang dianggap dapat mewakili populasi yang diteliti, maka hasil yang diperoleh dalam penelitian ini merupakan sesuatu yang bersifat konklusif untuk populasi dari mana sampel tersebut diambil (Malhotra, 1996).

\section{Populasi dan Sampel}

Penelitian dilakukan di Pasar Tas 5 Pujasera No. 9, Plintahan, Wonoplintahan, Prambon, Kabupaten Sidoarjo. Populasi pada penelitian ini jumlahnya tidak terbatas dan tidak diketahui jumlahnya. Populasi yang dalam penelitian ini adalah konsumen yang berkunjung dan melakukan pembelian di Kedai Warsu Cofee. Sampel pada penelitian ini sebanyak 87 responden, menggunakan rumus seperti yang dikemukakan oleh ${ }^{[20]}$ sebagai berikut:

$$
n=\frac{N}{1+N(a)^{2}}
$$

Keterangan :

$\mathrm{n}=$ Ukuran sampel/Jumlah responden

$\mathrm{N}=$ Ukuran Populasi

$\alpha=$ Toleransi ketidaktelitian (dalam persen).

Dalam rumus Slovin ada ketentuan sebagai berikut:

Nilai a $=0,1(10 \%)$ untuk populasi minimal 476

$$
\begin{gathered}
\mathrm{n}=\frac{617}{1+617(0,1)^{2}} \\
\mathrm{n}=\frac{617}{7,17} \\
\mathrm{n}=86,05
\end{gathered}
$$

Bila dibulatkan dan disesuaikan dalam penelitian maka banyaknya sampel sebesar 87 responden.

\section{Jenis dan Sumber Data}

Jenis data dalam penelitian ini menggunakan data kuantitatif. Sumber data yang digunakan dalam penelitian ini ada dua yaitu data primer dan data sekunder. Data Primer diperoleh dari penyebaran kuesioner dan wanacara dengan Pengelola kedai. Sedangkan data sekunder diperoleh dari studi literature dan data berkaitan dengan kondisi internal dari Kedai Warsu

\section{Teknik Pengumpulan Data}

Teknik pengumpulan data pada penelitian ini menggunakan kuesioner. Menurut Sekaran (2006) kuesioner adalah daftar pertanyaan yang tertulis dan telah di rumuskan sebelumnya yang akan di jawab oleh responden, biasanya dalam alternative yang di definisikan dengan jelas.

Kuesioner sendiri dapat di berikan secara pribadi, disuratkan kepada responden atau dapat di sebarkan secara elektronik. Dalam penelitian ini kuesioner di sebarkan kepada responden yang pernah membeli di Kedai Warsu Cofee.

\section{PEMBAHASAN}

Pembahasan penelitian ini dilakukan secara bertahap yang meiputi:

\section{Pengujian Instrumen Penelitian \\ Uji Validitas}

Menurut Ghozali (2018) uji validitas di gunakan untuk menguji valid atau tidaknya suatu kuesioner. suatu kuesioner dikatakan valid apabila pernyataan kuesioner mampu untuk mengungkapkan sesuatu yang akan diukur oleh kuesioner tersebut. 
Pada hasil pengujian validitas menyatakan bahwa hasil penelitian seluruh item pernyataan kuesioner dari variabel (X) dan variabel (Y) memiliki nilai korelasi diatas $r_{\text {kritis }}$ yang bernilai $0,30(>0,30)$ sehingga dapat dikatakan bahwa item pernyataan kuesioner dari varibel (X) dan Variabel (Y) dinyatakan valid dan dapat digunakan untuk menggukur variabel yang telah diteliti.

\section{Uji Reliabilitas}

Uji reliabilitas adalah alat ukur untuk mengukur kuesioner yang merupakan indikator dari variabel atau konstruk. Suatu kuesioner dikatakan reliabel jika jawaban seseorang terhadap pernyataan yang tersedia adalah konsisten atau stabil dari waktu ke waktu (Ghozali, 2018).

Tabel 1

\section{Uji Validitas}

\begin{tabular}{|c|c|c|c|c|}
\hline Variabel & Indikator & $\underline{r}_{\text {hitung }}$ & $\mathbf{r}_{\text {kritis }}$ & Keterangan \\
\hline \multirow{5}{*}{$\begin{array}{l}\text { Kualitas } \\
\text { Produk } \\
\text { (X1) }\end{array}$} & $\mathrm{X}_{1.1}$ & 0,690 & \multirow{16}{*}{0,30} & Valid \\
\hline & $\mathrm{X}_{1.2}$ & 0,662 & & Valid \\
\hline & $\mathrm{X}_{1.3}$ & 0,745 & & Valid \\
\hline & $\mathrm{X}_{1.4}$ & 0,697 & & Valid \\
\hline & $\mathrm{X}_{1.5}$ & 0,702 & & Valid \\
\hline \multirow{3}{*}{$\begin{array}{c}\text { Harga } \\
\text { (X2) }\end{array}$} & $\mathrm{X}_{2.1}$ & 0,815 & & Valid \\
\hline & $\mathrm{X}_{2.2}$ & 0,756 & & Valid \\
\hline & $\mathrm{X}_{2.3}$ & 0,816 & & Valid \\
\hline \multirow{4}{*}{$\begin{array}{l}\text { Kulitas } \\
\text { Pelayanan } \\
\text { (X3) }\end{array}$} & $X_{3.1}$ & 0,613 & & Valid \\
\hline & $X_{3.2}$ & 0,690 & & Valid \\
\hline & $X_{3.3}$ & 0,741 & & Valid \\
\hline & $\mathrm{X}_{3.4}$ & 0,765 & & Valid \\
\hline \multirow{4}{*}{$\begin{array}{c}\text { Kepuasan } \\
\text { Konsumen } \\
\text { (Y) }\end{array}$} & $\mathrm{Y}_{._{1}}$ & 0,660 & & Valid \\
\hline & $\mathrm{Y} .2_{2}$ & 0,691 & & Valid \\
\hline & Y.3 & 0,775 & & Valid \\
\hline & $\mathrm{Y}_{\cdot 4}$ & 0,820 & & Valid \\
\hline
\end{tabular}

Sumber: Data diolah

Tabel 2

Hasil Uji Reliabilitas

\begin{tabular}{|c|c|c|c|}
\hline Variabel & $\begin{array}{c}\text { Cronbach's } \\
\text { Alpha }\end{array}$ & $\mathbf{r}_{\text {kritis }}$ & Keterangan \\
\hline Kualitas & & \multirow{6}{*}{0,60} & \\
\hline $\begin{array}{l}\text { Produk } \\
\text { (X1) }\end{array}$ & 0,737 & & Reliabel \\
\hline $\begin{array}{l}\text { Harga } \\
(\mathrm{X} 2)\end{array}$ & 0,708 & & Reliabel \\
\hline Kualitas & & & \\
\hline $\begin{array}{l}\text { Pelayanan } \\
\text { (X3) }\end{array}$ & 0,661 & & Reliabel \\
\hline $\begin{array}{c}\text { Kepuasan } \\
\text { Konsumen } \\
(\mathrm{Y})\end{array}$ & 0,722 & & Reliabel \\
\hline
\end{tabular}

Sumber : Data diolah
Berdasarkan Tabel 2 dapat dilihat bahwa variabel kualitas produk (X1), harga (X2), kualitas pelayanan (X3) dan kepuasan konsumen (Y) dapat dilihat masing-masing variabel berstatus reliabel karena nilai Cronbach Alpha > 0,60. Sehingga variabel ini dapat digunakan untuk melanjutkan penelitian selanjutnya.

\section{Uji Asumsi Klasik}

\section{Uji Linieritas}

Dari hasil pengujian linieritas menunjukkan bahwa variabel kualitas produk $\left(\mathrm{X}_{1}\right)$, harga $\left(\mathrm{X}_{2}\right)$, dan kualitas pelayanan $\left(\mathrm{X}_{3}\right)$ mempunyai hubungan yang linier terhadap variabel kepuasan konsumen (Y). Hal ini menunjukkan bahwa variabel kualitas produk, harga dan kualitas pelayanan berpola linier terhadap kepuasan konsumen.

\section{Tabel 3}

Hasil Uji Linearitas

\begin{tabular}{ccccc}
\hline Variabel & F & $\begin{array}{c}\text { Sig. } \\
\text { Linearity }\end{array}$ & Kondisi & Kesimpulan \\
\hline $\mathrm{X}_{1} \square \mathrm{Y}$ & 182,353 & 0,000 & Sig. $<0,05$ & Linier \\
\hline $\mathrm{X}_{2} \square \mathrm{Y}$ & 56,999 & 0,000 & Sig. $<0,05$ & Linier \\
\hline $\mathrm{X}_{3} \square \mathrm{Y}$ & 171,174 & 0,000 & Sig. $<0,05$ & Linier \\
\hline
\end{tabular}

Sumber : data diolah

\section{Uji Normalitas}

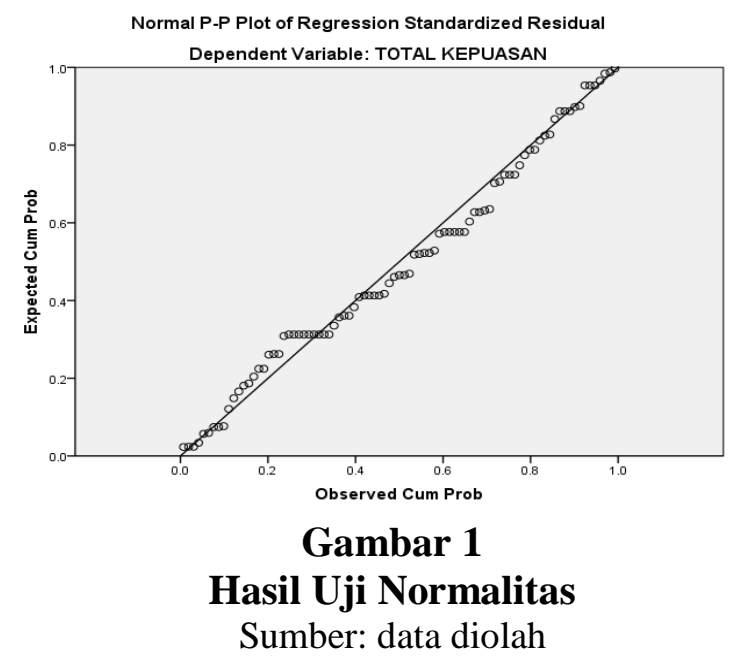

Berdasarkan hasil uji pengujian normalitas penelitian ini menunjukkan bahwa grafik Normal Probability Plot yang mensyaratkan bahwa bersebaran data harus berada diwilayah garis diagonal dan mengikuti arah garis diagonal. Berdasarkan gambar diatas maka hasil ini telah memenuhi syarat Normal Probabily Plot. Artinya data dalam penelitian ini berasal dari populasi yang berdistribusi normal. 
Tabel 4

Hasil Uji Kolinearitas

\begin{tabular}{ccc}
\hline \multirow{2}{*}{ Model } & \multicolumn{2}{c}{ Collinearity Statistics } \\
\cline { 2 - 3 } & $\begin{array}{c}\text { Toleranc } \\
\text { e }\end{array}$ & VIF \\
\hline $\begin{array}{c}\text { Kualitas Produk } \\
\text { (Total X1) }\end{array}$ &, 301 & 3,326 \\
\hline $\begin{array}{c}\text { Harga } \\
\text { (Total X2) }\end{array}$ &, 612 & 1,634 \\
\hline $\begin{array}{c}\text { Kualitas } \\
\text { Pelayanan } \\
\text { (Total X3) }\end{array}$ &, 248 & 4,025 \\
\hline
\end{tabular}

Sumber : data diolah

a. Dependent Variable: Kepuasan

Konsumen (Total Y)

\section{Uji Multikolonieritas}

Berdasarkan hasil uji pengujian multikolinieritas dapat diketahui bahwa nilai VIF lebih kecil dari $10(<10)$ dan nilai toleransi lebih besar dari $0,1(>0,1)$ sehingga dapat disimpulkan bahwa regresi tidak terdapat gejala multikolinieritas. Artinya bahwa diantara variabel bebas (kualitas produk, harga dan kualitas pelayanan) tidak saling mempengaruhi.

\section{Uji Heterokedastisitas}

Pada hasil pengujian heteroskedastisitas diatas dapat dilihat bahwa titik-titik data yang digunakan pada penelitian ini menyebar disekitar angka 0 dari garis sumbu $\mathrm{Y}$. Hal ini berarti bahwa variabel bebas tidak terjadi gejala heteroskedatisitas.

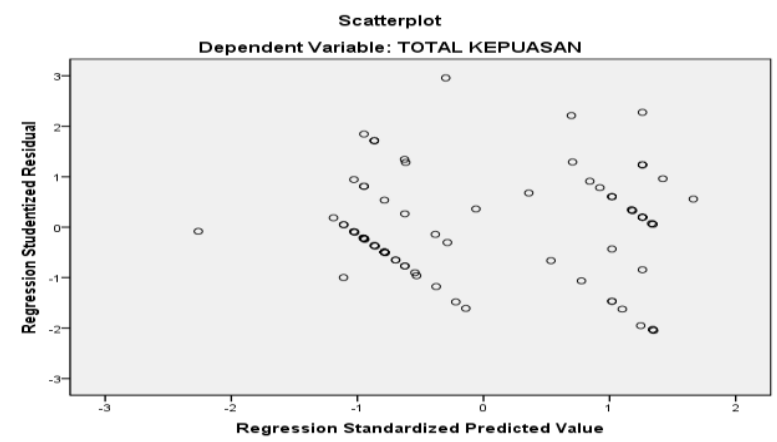

Gambar 2

\section{Hasil Uji Heteroskedastisitas}

Sumber data diolah

\section{Uji Autokorelasi}

Pada hasil pengujian autokorelasi penelitian ini, nilai Durbin-Watson dari perhitungan DW sebesar 2,186 dan nilai ini berarti bahwa $\mathrm{dL}<\mathrm{d}<$ $4-\mathrm{dU}(1,5808<2,186<2,2768)$. Sehingga dapat disimpulkan bahwa dalam penelitian ini tidak terdapat autokorelasi.

\section{Analisis Regresi Linier Berganda}

Berdasarkan Tabel 5 diatas dapat diketahui model regresinya dari keempat variabel sebagai berikut:

$$
\begin{aligned}
& \mathrm{Y}=0,643+0,394 \mathrm{X}_{1}+0,264 \mathrm{X}_{2}+0,275 \mathrm{X}_{3}+\mathrm{e} \\
& \text { Keterangan: } \\
& \mathrm{Y}=\text { kepuasan konsumen } \\
& \alpha \quad=\text { konstanta } \\
& \mathrm{b}_{1}=\text { koefisien regresi } \mathrm{X}_{1} \\
& \mathrm{~b}_{2}=\text { koefisien regresi } \mathrm{X}_{2} \\
& \mathrm{~b}_{3}=\text { koefisien regresi } \mathrm{X}_{3} \\
& \mathrm{X}_{1}=\text { kualitas produk } \\
& \mathrm{X}_{2}=\text { harga } \\
& \mathrm{X}_{3}=\text { kualitas pelayanan } \\
& \mathrm{e}=\text { standart error }
\end{aligned}
$$

\begin{tabular}{|c|c|c|c|c|c|}
\hline \multirow[t]{2}{*}{ Model } & \multicolumn{2}{|c|}{$\begin{array}{c}\text { Unstandardized } \\
\text { Coefficients }\end{array}$} & \multirow{2}{*}{$\begin{array}{c}\text { Standardized } \\
\text { Coefficients } \\
\text { Beta }\end{array}$} & \multirow[t]{2}{*}{$\mathbf{T}$} & \multirow[t]{2}{*}{ Sig } \\
\hline & B & $\begin{array}{c}\text { Std. } \\
\text { Error }\end{array}$ & & & \\
\hline (Constant) & 0,643 & 1,038 & & ,620 & ,537 \\
\hline $\begin{array}{l}\text { Kualitas } \\
\text { Produk } \\
\text { (Total X1) }\end{array}$ & ,394 & ,028 & ,487 & 4,78 & ,000 \\
\hline $\begin{array}{l}\text { Harga (Total } \\
\mathrm{X} 2 \text { ) }\end{array}$ & ,264 & ,099 & ,190 & 2,66 & ,009 \\
\hline $\begin{array}{l}\text { Kualitas } \\
\text { Pelayanan } \\
\text { (Total X3) } \\
\end{array}$ & ,275 & ,110 & ,280 & 2,50 & ,015 \\
\hline
\end{tabular}

\section{Tabel 5}

\section{Hasil Uji Regresi Linier Berganda} Coefficients $^{\text {a }}$

Sumber : data diolah

\section{Pengujian Hipotesis}

Uji Parsial (Uji t)

Pengaruh Kualitas Produk Terhadap Kepuasan Konsumen

Berdasarkan tabel uji t diperoleh $t_{\text {hitung }}$ sebesar 4,779 hal ini menunjukkan $t_{\text {hitung }} 4,779$ lebih besar dari $\mathrm{t}_{\text {tabel }} 1$ 1,662. Dengan demikian $\mathrm{H}_{0}$ ditolak dan $\mathrm{H}_{1}$ diterima, artinya variabel kualitas produk mempunyai pengaruh yang signifikan terhadap kepuasan konsumen Kedai Warsu Coffe.

Pengaruh Harga Terhadap Kepuasan Konsumen Berdasarkan tabel uji $t$ diperoleh $\mathrm{t}_{\text {hitung }}$ sebesar 2,658 . Hal ini menunjukkan $t_{\text {hitung }} 2,658$ lebih besar dari $\mathrm{t}_{\text {tabel }} 1,662$. Hal ini berarti bahwa $\mathrm{H}_{0}$ ditolak 
dan $\mathrm{H}_{2}$ diterima, artinya variabel harga mempunyai pengaruh secara signifikan tehadap kepuasan konsumen.

Pengaruh Kualitas Pelayanan Terhadap Kepuasan Konsumen

Berdasarkan tabel uji $\mathrm{t}$ diperoleh $\mathrm{t}_{\text {hitung }} 2,494$. Hal ini menunjukkan $t_{\text {hitung }}$ 2,494 lebih besar dari $t_{\text {tabel }}$ 1,662. Dengan demikian $\mathrm{H}_{0}$ ditolak dan $\mathrm{H}_{3}$ diterima, artinya variabel kualitas layanan mempunyai pengaruh yang signifikan terhadap kepuasan konsumen.

\section{Uji Simultan (Uji F)}

Dari hasil pengujian secara simultan menunjukkan nilai $\mathrm{F}_{\text {hitung }}$ sebesar 78,939 sedangkan $F_{\text {tabel }}$ pada tingkat kepercayaan signifikansi sebesar 5\% dan df sebesar $\mathrm{k}=3$ dan df2 = n-k-1 (87-3$1=83$ ) maka didapat nilai $\mathrm{F}_{\text {tabel }}$ sebesar 2,71. Oleh karena itu $\mathrm{F}_{\text {hitung }} 78,939$ lebih besar dari $\mathrm{F}_{\text {tabel }} 2,71$ dan tabel diatas juga menunjukkan nilai sig $=$ 0,000 yang lebih kecil dari $\alpha=0,05$ maka dapat diartikan variabel bebas mempunyai pengaruh secara simultan terhadap variabel terikat.

Tabel 6

Hasil Uji Pengaruh Simultan

\begin{tabular}{lccccc}
\hline Model & $\begin{array}{c}\text { Sum of } \\
\text { Square } \\
\text { s }\end{array}$ & Df & $\begin{array}{c}\text { Mean } \\
\text { Squar } \\
\text { e }\end{array}$ & F & Sig \\
\hline Regressio & 228,02 & 3 & 76,005 & 78,94 &, $000^{\text {a }}$ \\
n & & & & & \\
Residual & 79,92 & 83 & 0,963 & & \\
Total & 307,93 & 86 & & & \\
\hline
\end{tabular}

a. Predictors: (Constant), Kualitas Pelayanan (Total X3), Harga (Total X2), Kualitas Produk (Total X1)

b. Dependent Variable: Kepuasan Konsumen (Total Y)

Sumber: data diolah

\section{Koefesien Korelasi Berganda (Uji R)}

Pada Tabel 7 menunjukkan hasil nilai uji $\mathrm{R}$ adalah sebesar 0,861 artinya bahwa hubungan antara variabel bebas $(\mathrm{X})$ dan variablel terikat $(\mathrm{Y})$ sangat kuat, karena hasil dari uji $\mathrm{R}$ mendekati angka 1 .

\section{Koefesien Determinan Berganda ( $\mathbf{U j i} \mathbf{R}^{2}$ )}

Pada Tabel 7 menunjukkan bahwa nilai dari koefisien determinan $\left(\mathrm{R}^{2}\right)$ pada hasil uji koefisien determinan berganda (uji $\mathrm{R}^{2}$ ) adalah sebesar 0,740 atau $74 \%$, sehingga dapat dijelaskan bahwa variabel penilaian kualitas produk $\left(\mathrm{X}_{1}\right)$, harga $\left(\mathrm{X}_{2}\right)$, dan kualitas pelayanan $\left(X_{3}\right)$ dapat menjelaskan tentang variabel kepuasan konsumen $(\mathrm{Y})$ dalam penelitian ini dan sisanya sebesar $26 \%$ dijelaskan oleh variabel lain yang tidak dijadikan objek dalam penelitian ini.

Tabel 7

Hasil Uji Korelasi

\begin{tabular}{|c|c|c|c|}
\hline $\mathbf{R}$ & $\mathbf{R}^{2}$ & $\begin{array}{c}\text { Adjuste } \\
\text { d R R }^{2}\end{array}$ & $\begin{array}{l}\text { Std. Error } \\
\text { of the } \\
\text { Estimate }\end{array}$ \\
\hline $861^{\mathrm{a}}$ &, 740 & ,731 & ,981 \\
\hline \multicolumn{4}{|c|}{$\begin{array}{l}\text { a. Predictors: (Constant), Kualitas } \\
\text { Pelayanan (Total X3), Harga (Total } \\
\text { X2), Kualitas Produk (Total X1) }\end{array}$} \\
\hline $\begin{array}{l}\text { b. De } \\
\text { Kons }\end{array}$ & $\begin{array}{l}\text { ndent } \\
\text { men }(\end{array}$ & $\begin{array}{l}\text { Jariable: K } \\
\text { otal Y) }\end{array}$ & puasan \\
\hline
\end{tabular}

Sumber : data diolah

\section{PEMBAHASAN}

Hasil analisis data membuktikan bahwa kualitas produk berpengaruh secara positif dan signifikan terhadap kepuasan konsumen. Ini berarti bahwa ketika konsumen melihat kualitas produk yang ditawarkan kedai Warsu Cofee baik, maka konsumen merasakan kepuasan yang tinggi atas Kedai Warsu Coffe. Hasil penelitian ini didukung oleh penelitian yang dilakukan oleh Runtunuwu dan Oroh (2014) yang membuktikan bahwa kualitas produk berpengaruh terhadap kepuasan.

Hasil analisis data juga membuktikan bahwa harga berpengaruh secara positif dan signifikan terhadap kepuasan konsumen. Artinya ketika harga produk kedai Warsu coffe dinilai terjangkau oleh konsumen, maka konsumen akan merasam puas dengan kedai kopi tersebut. Hasil penelitian ini didukung oleh Manus dan Lumanauw (2015) yang membutikan bahwa harga secara parsial berpengaruh terhadap kepuasan.

Hasil analisis data membuktikan bahwa kualitas pelayanan berpengaruh secara positif dan signifikan terhadap kepuasan konsumen. Ini berarti bahwa ketika konsumen merasakan kualitas layanan dari kedai coffe Warsu baik, maka konsumen akan merasa puas dengan kedai kopi tersebut Hasil penelitian ini didukung oleh Zaiullah, and Akhter (2014) bahwa kualitas layanan secara langsung mempengaruhi kepuasan.

Dari ketiga faktor yang mempengaaaruhi kepuasan konsumen Kedai Warsuu Cofee maka kulaitas produk menjadi faktor yang dominan mempengaruhi kepuasan. Ini sesuai dengan karakteristik dari Kedai Warsu Cofee sebagai penyedia produk yang disertai jasa tambahan, maka kualitas produk menjadi ha utama yang diperhatikan konsumen ketika memilih kedai. 
Dengan demikian kulaitas produk menjadi kunci utama yang dapat memuaskan pelanggan dari sebuah kedai kopi.

Implikasi manajerial yang dapat diambil dari hasil penelitian inii adalah bahwasnya untuk usaha kuliner, kulaitas produk, kulaitas layanan dan harga menjadi faktor peneltu dalam kepuasan konsumen. Dalam usaha rumah makan yang memiliki nkarakteristik sebagai produk disertai jasa tambahan, menunjukkan bahwa kulaitas produk dan layanan adalah penting, walaupun hasil penelitian menunjukkan bahwa kualitas produk lebih dominan mempengaruhi kepuasan konsumen, kualitas layanan juga penting. Maka untuk setiap usaha kuliner selain memperbaiki kualitas makanan dan minuman yang disajikan, perhatian terhadap layanan dan fasilitas seperti tempat yang nyaman, wifi, hiburan juga penting untuk memajukan usaha kuliner tersebut. Disamping harga yang harus bisa menyesuaikan pada kemampuan dari target pasar usaha kuliner tersebut.

\section{PENUTUP}

\section{Kesimpulan}

Berdasarkan hasil penelitian dan pembahasan diatas, maka dapat disimpulkan beberapa hal sebagai berikut:

1. Penilaian variabel kualitas produk, harga dan kualitas pelayanan mempunyai pengaruh secara parsial dan semua variabel bebas mempunyai pengaruh yang signifikan terhadap kepuasan konsumen. Hal ini menjelaskan bahwa konsumen telah mengetahui kualitas produk, harga maupun perbandingan kualitas pelayanan yang telah dilakukan terhadap kedai Warsu Coffe dilaksanakan dengan baik sehingga mampu menciptakan kepuasan konsumen.

2. Variabel kualitas produk, harga dan kualitas pelayanan mempunyai pengaruh secara simultan terhadap kepuasan konsumen, Semua variabel bebas berjalan simultan dengan baik terhadap kepuasan konsumen dan mengalami peningkatan yang signifikan. Hal ini menjelaskan bahwa kualitas produk, harga dan kualitas pelayanan yang diberikan oleh kedai Warsu Coffe sudah berjalan dengan baik. Sehingga memberi dampak positif yang menciptakan kepuasan konsumen.

3. Diantara variabel kualitas produk, harga dan kualitas pelayanan, variabel kualitas produk yang mempunyai pengaruh dominan terhadap kepuasan konsumen kedai Warsu Coffe, ini menunjukkan bahwa kedai Warsu Coffe mempunyai kualitas produk yang baik, karena konsumen telah menilai tingginya tingkat kualitas produk maka tingkat kepuasan juga akan tinggi. Sedangkan variabel kualitas pelayanan dalam penelitian ini mempunyai nilai signifikan yang paling rendah, karena ada konsumen yang lebih cermat membandingkan dan mengukur pelayanan yang diberikan kedai Warsu Coffe dengan kedai lain.

\section{Keterbatasan dan Rekomendasi}

1. Saran Bagi Perusahaan

Dari hasil penelitian ini maka manajemen kedai Warsu Coffe sebaiknya memperhatikan masalah kualitas pelayanan, karena kualitas pelayanan juga memiliki pengaruh terhadap kepuasan konsumen. Kualitas pelayanan yang baik akan menciptakan kepuasan yang tinggi. Kualitas pelayanan harus selalu ditingkatkan agar konsumen merasa nyaman dan tidak lagi membandingkan dan mengukur pelayanan yang diberikan kedai oleh kedai lain. Sebaiknya pemilik kedai Warsu Coffe harus mengadakan evaluasi terhadap kinerja pelayan kedai, dengan begitu akan mengetahui sisi kelemahan dalam pelayanan yang sudah diberikan.

2. Saran Bagi Penelitian selanjutnya

Dalam penelitian ini lebih baik untuk dikembangkan lagi dalam menambahkan variabel sehingga dapat menambah pengetahuan diluar dari variabel yang digunakan dlam penelitian ini. karena hasil penelitian ini pada variabel kualitas pelayanan masih tergolong kurang memuaskan yang seharusnya pelayanan yang diterima oleh konsumen dapat dikatakan baik. Untuk itu penelitian selanjutnya juga diharapkan mampu mengembangkan teori atau kajian penelitian pada objek penelitian yang lebih luas.

\section{DAFTAR PUSTAKA}

Alma, B. (2000). Manajemen Pemasaran dan Pemasaran Jasa. Bandung: Alfabeta.

Amrullah, Siburian, \& Zainurosalamia. (2016). Pengaruh Kualitas Produk dan Kualitas Layanan Terhadap Keputusan Pembelian Sepeda Motor Honda.

Ghozali, I. (2018). Aplikasi Analisis Multivariat. Semarang: Universitas Diponegoro.

Handoko, B. (2016). Pengaruh Harga dan Kualitas Pelayanan Terhadap Kepuasan 
Konsumen di Titipan Kilat JNE Medan. Junal Ilmiah Manajemen dan Bisnis.

Kotler , P., \& Amstrong, G. (2001). Prinsip Prinsip Pemasaran . Jakarta: Erlangga.

Lupiyoadi, R. (2013). Manajemen Pemasaran Jasa . Jakarta: Salemba Empat .

Manus, F. W., \& Lumanauw, B. (2015). Kualitas Produk, Harga dan Kualitas pelayanan Pengaruhnya Terhadap Kepuasan Pelanggan Kartu Prabayar Tri di Kelurahan Wawalintauan VillageTondano. Jurnal EMBA.

Runtunuwu, J. G., Oroh, S., \& Taroreh, R. (2014). Pengaruh Kualitas Produk, Harga dan Kualitas Pelayanan Terhadap Kepuasan
Pengguna Cafe Dan Resto Cabana Manado. EMBA.

Sekaran, U. (2006). Research Methods For Business. Jakarta.

Solihin, I. (2014). Pengantar Bisnis. Jakarta.

Swastha, B., \& Irawan. (2003). Manajemen Pemasaran Modern. Yogyakarta: Liberty Yogyakarta.

Yuniar, V., \& Setyorini, R. (2015). Pengaruh Kualitas Pelayanan Terhadap Kepuasan Konsumen Pda Perusahaan Jasa EMKL Saputra Trans Abadi Cirebon. 